Review

\title{
New Resorbable Membrane Materials for Guided Bone Regeneration
}

\author{
You-Young Jo ${ }^{1}$ and Ji-Hyeon $\mathrm{Oh}^{2, *}$ \\ 1 Sericultural and Apicultural Materials Division, National Academy of Agricultural Science, \\ Rural Development Administration, Wanju-gun 55365, Korea; yyjo@korea.kr \\ 2 Department of Dentistry, Yonsei University Wonju College of Medicine, Wonju 26426, Korea \\ * Correspondence: haruna348@naver.com; Tel.: +82-33-640-3139
}

Received: 20 September 2018; Accepted: 1 November 2018; Published: 4 November 2018

\begin{abstract}
Membranes are used for guided bone regeneration (GBR) in bone defects. Resorbable membranes of collagen or aliphatic polyesters that do not require secondary surgery for removal, unlike non-resorbable membranes, have been marketed for GBR. Platelet rich fibrin membrane and silk-based membranes have recently been assessed as membranes for GBR. Studies have been conducted on resorbable membranes with new materials to improve physical properties and bone regeneration without any adverse inflammatory reactions. However, clinical research data remain limited. More studies are needed to commercialize such membranes.
\end{abstract}

Keywords: membranes; bone regeneration; collagen; polyesters; platelet rich fibrin; silk

\section{Introduction}

Guided bone regeneration (GBR) is a widely used technique for bone regeneration on alveolar bone defects [1,2]. GBR uses a membrane as a physical barrier to prevent epithelial and connective tissue in the bone defect [3-6]. The selection criteria for a membrane used for GBR are important [7].

Ideal membrane characteristics include tissue integration, cell occlusivity, clinical manageability, space-making, and biocompatibility [8,9]. However, no membrane satisfies all of these conditions [9].

GBR membranes can be divided into two types-resorbable and non-resorbable-depending on their degradation characteristics [10]. Non-resorbable membranes have the disadvantage of requiring secondary surgery for removal that can cause additional pain, discomfort, infection, and economic burden [3]. Resorbable membranes have been developed to overcome this problem [1].

The purpose of this paper is to selectively review new resorbable membrane materials used for GBR. In this paper, the changes in characteristics of membranes by adding additives to commercial membranes are described, unlike previous papers.

\section{Collagen}

Collagen has been used as a resorbable membrane for GBR [11]. Collagen membrane has the advantages of low antigenicity, high biocompatibility, and excellent cell affinity, but pure collagen has the disadvantage of being difficult to handle due to a paucity of physical properties, and it is degraded quickly [12-14].

Cross-linking methods improve the physical properties of the collagen membrane and effectively extend the absorption time $[12,15,16]$. Among the chemical cross-linking agents, glutaraldehyde is the most widely used, but it has been reported to be cytotoxic $[17,18]$. To overcome the drawbacks of this method, other cross-linking agents with low cytotoxicity have been developed. Diphenylphosphorylazide (DPPA) provides biocompatibility and good handling characteristics without 
any cytotoxic effects $[19,20]$. 1-Ethyl-3-(3-dimethylaminopropyl) carbodiimide (EDC) cross-linked collagen membrane has a high resistance to enzymatic digestion and low cytotoxicity [21,22]. Epigallocatechin-3-gallate (EGCG) cross-linked collagen membrane has better mechanical properties and anti-inflammatory effects $[23,24]$.

Several studies have reported changes in mechanical properties and outcomes of GBR by adding additives to collagen membrane (Table 1).

Table 1. Experimental studies evaluating the performance of modified collagen membranes.

\begin{tabular}{|c|c|c|c|}
\hline $\begin{array}{l}\text { Experimental } \\
\text { Model }\end{array}$ & $\begin{array}{c}\text { Experimental Groups } \\
\text { (Membrane with/without New Material) }\end{array}$ & Main Findings & Reference \\
\hline $\begin{array}{l}5.25 \text { mm Calvarial } \\
\text { defect (rat) }\end{array}$ & $\begin{array}{ll}\text { (i) Sham } \\
\text { (ii) Commercial collagen membrane } \\
\text { (GenDerm) } \\
\text { (iii) } \begin{array}{l}\text { Mineralized polyanionic collagen } \\
\text { membrane (PAC), without impregnation }\end{array} \\
\text { with HA and cross-linked } \\
\text { with glutaraldehyde } \\
\text { (iv) PAC, impregnated with } 25 \text { cycles of HA } \\
\text { and cross-linked with glutaraldehyde } \\
\text { (v) PAC, impregnated with } 75 \text { cycles of HA } \\
\text { and cross-linked with glutaraldehyde }\end{array}$ & $\begin{array}{l}\text { - The percentage of new bone } \\
\text { formation in (iii), (iv), and (v) was } \\
\text { higher than (i) and (ii) } \\
\text { No significant difference in bone } \\
\text { formation among (iii), (iv), and (v) }\end{array}$ & [13] \\
\hline $\begin{array}{l}5 \text { mm Calvarial } \\
\text { defect (rat) }\end{array}$ & $\begin{array}{ll}\text { (i) } & \text { Untreated collagen membranes } \\
\text { (ii) } & \text { EGCG cross-linked collagen membranes } \\
\text { (iii) } & \text { Nano-HA modified collagen membranes } \\
\text { (iv) } & \text { Nano-HA modified } \\
& \text { EGCG-collagen membranes }\end{array}$ & $\begin{array}{l}\text { - The thickness of the regenerated } \\
\text { bone was significantly higher in (iv) } \\
\text { than in (ii) and (iii) } \\
\text { (ii) and (iii) exhibited less bone } \\
\text { regenerative ability than (i) and (iv) }\end{array}$ & [25] \\
\hline $\begin{array}{l}5 \text { mm Calvarial } \\
\text { defect (rat) }\end{array}$ & $\begin{array}{ll}\text { (i) } & \text { No membrane } \\
\text { (ii) Collagen-HA single-layer dense membrane } \\
\text { (iii) Collagen-HA double-layer membrane } \\
\text { (iv) Collagen membrane (Bio-Gide) }\end{array}$ & $\begin{array}{l}\text { - No significant difference between } \\
\text { (iv) and (ii)/(iii) }\end{array}$ & [26] \\
\hline $\begin{array}{l}\text { Osteoblast cell line } \\
\quad \text { (MC3T3-E1) }\end{array}$ & $\begin{array}{l}\text { Collagen/HA membrane } \\
\text { Three-layered membrane } \\
\text { Chitosan membrane }\end{array}$ & $\begin{array}{l}\text { - The tensile strength and elastic } \\
\text { modulus of (ii) increased by } \sim 2 \text { and } \\
3 \text { times, compared to (i) } \\
\text { - } \quad \text { (i) had better flexibility than (iii) } \\
\text { - The cells on (ii) proliferated to } \\
\text { significantly higher degrees than (iii) }\end{array}$ & [27] \\
\hline $\begin{array}{l}\text { Osteoblast cell line } \\
\text { (MG-64 and } \\
\text { MC3T3-E1) }\end{array}$ & $\begin{array}{l}\text { Three different chitosan concentrations }(0.5 \%, 1 \% \text {, } \\
\text { and } 2 \%) \text { and five different concentrations of } \\
\beta \text {-TCP }(0 \%, 17 \%, 29 \%, 38 \% \text {, and } 44 \%)\end{array}$ & $\begin{array}{l}\text { Chitosan concentrations up to } 2 \% \\
\text { and } \beta-\mathrm{TCP} \text { concentrations up to } 29 \% \\
\text { and } 38 \% \text { enhanced the tear } \\
\text { resistance and flexural strength of } \\
\text { collagen membrane } \\
\text { Cells had favorable viability on } \\
\beta-\mathrm{TCP} / \text { chitosan/collagen } \\
\text { composite membrane as well as } \\
\text { chitosan-coated collagen membrane }\end{array}$ & [11] \\
\hline $\begin{array}{l}8 \text { mm Calvarial } \\
\text { defect (rat) }\end{array}$ & $\begin{array}{l}\text { (i) Collagen membrane } \\
\text { (ii) Collagen membrane treated with BMP-2 } \\
\text { (iii) Heparinized collagen membrane } \\
\text { containing bound BMP-7 } \\
\text { (iv) Heparinized collagen membrane } \\
\text { containing bound BMP-7 and treated } \\
\text { with BMP-2 }\end{array}$ & $\begin{array}{l}\text { (ii) had the largest new bone area at } \\
\text { week } 2 \text {; new bone areas in (iii) and } \\
\text { (iv) were similar } \\
\text { After } 8 \text { weeks, (iv) had the largest } \\
\text { new bone area, followed by (ii) } \\
\text { and (iii) }\end{array}$ & [28] \\
\hline $\begin{array}{l}4 \mathrm{~mm} \text { Mandibular } \\
\text { ramus defect (rat) }\end{array}$ & $\begin{array}{l}\text { (i) No treatment } \\
\text { (ii) Collagen membrane } \\
\text { (iii) Collagen membrane containing low-dose } \\
0.5 \mu \text { g of PDGF } \\
\text { (iv) Collagen membrane containing high-dose } 1 \\
\mu \mathrm{g} \text { of PDGF } \\
\text { (v) Collagen membrane containing low-dose } \\
20 \mu g \text { of GDF-5 } \\
\text { (vi) Collagen membrane containing high-dose } \\
60 \mu \text { g of GDF-5 }\end{array}$ & $\begin{array}{l}\text { (iii) and (iv) significantly enhanced } \\
\text { bone regeneration compared to (i) } \\
\text { and (ii) } \\
\text { (v) and (vi) significantly accelerated } \\
\text { bone regeneration to an even greater } \\
\text { extent than (iii) and (iv) } \\
\text { The enhanced bone formation had } \\
\text { a dose-dependent response (vi }>\mathrm{v}> \\
\text { iv }>\text { iii) }\end{array}$ & [29] \\
\hline
\end{tabular}


Collagen/hydroxyapatite (HA) membrane is known to have good biocompatibility, osteoconductivity, and a similar composition and structure to natural bone $[25,27]$. However, collagen/HA membrane does not have a substantially positive effect on bone regeneration $[13,25,26]$.

$\beta$-Tricalcium phosphate $(\beta-\mathrm{TCP}) /$ chitosan/collagen membrane possesses good cell viability and superior mechanical properties, as $\beta$-TCP improves mechanical properties related to space maintenance and stability, and chitosan chemically connects $\beta-\mathrm{TCP}$ and collagen [11,27]. Only in vitro studies have been conducted; additional in vivo studies on the effects of bone regeneration are required.

Bone morphogenetic proteins (BMPs), members of the transforming growth factor- $\beta$ (TGF- $\beta$ ) superfamily, are multifunctional growth factors. BMP-2 and BMP-7, in particular, play important roles in osteoblast differentiation [28]. BMP-2 treated collagen membrane showed significantly more new bone formation than collagen membrane. Furthermore, heparinized collagen membrane containing bound BMP-7 and treated with BMP-2 resulted in significantly more new bone formation than collagen membrane [28].

The released growth/differentiation factor 5 (GDF-5), a member of the TGF- $\beta$ superfamily, from collagen membrane, significantly increased cell proliferation and osteogenic gene expression. Collagen membrane with GDF- 5 significantly enhanced and accelerated bone regeneration compared to the platelet-derived growth factor (PDFG), without cytotoxicity [29].

\section{Aliphatic Polyesters}

Aliphatic polyesters, such as poly(lactic acid) (PLA), poly(glycolic acid) (PGA), poly(e-caprolactone) (PCL), poly(hydroxy valeric acid), poly(hydroxy butyric acid), and their copolymers, are another category of synthetic polymers and have been used as preparation materials for GBR membrane $[4,30,31]$. The advantages of aliphatic polyesters are that they are bioresorbable, and possess good processability and manageability, but their disadvantages include a lack of rigidity and stability [31]. Studies have been conducted to increase their advantages and reduce their disadvantages by modifying, mixing, and adding additives rather than using aliphatic polyesters alone (Table 2).

Table 2. Experimental studies evaluating the performance of modified aliphatic polyester membranes.

\begin{tabular}{|c|c|c|c|c|}
\hline Experimental Model & & $\begin{array}{c}\text { Experimental Groups } \\
\text { Membrane with/without New Material) }\end{array}$ & Main Findings & Reference \\
\hline $\begin{array}{l}5 \mathrm{~mm} \text { Calvarial defect } \\
\text { (rat) }\end{array}$ & $\begin{array}{l}\text { (i) } \\
\text { (ii) } \\
\text { (iii) } \\
\text { (iv) }\end{array}$ & $\begin{array}{l}\text { Bi-layer PLGA membrane }\left(-30^{\circ} \mathrm{C} \text { cooling }\right) \\
\text { Bi-layer PLGA membrane }\left(-70{ }^{\circ} \mathrm{C} \text { cooling }\right) \\
\text { PLGA membrane (GC membrane) } \\
\text { Sham }\end{array}$ & $\begin{array}{l}\text { The solid layer of (ii) was thicker } \\
\text { than (i); comparatively, (iii) had } \\
\text { a solid surface and uniform layer } \\
\text { (i) and (ii) had significantly } \\
\text { increased volume ratios of newly } \\
\text { formed bone compared to (iii) } \\
\text { and (iv) } \\
\text { (i), (ii), and (iii) had similar } \\
\text { biodegradation behaviors }\end{array}$ & [32] \\
\hline $\begin{array}{l}5 \mathrm{~mm} \text { Calvarial defect } \\
\text { (rat) }\end{array}$ & $\begin{array}{l}\text { (i) } \\
\text { (ii) } \\
\text { (iii) } \\
\text { (iv) }\end{array}$ & $\begin{array}{l}\text { PCL membrane } \\
\text { PCL/PLGA membrane } \\
\text { PCL/gelatin membrane } \\
\text { PCL/BCP membrane }\end{array}$ & $\begin{array}{l}\text { - Bone regeneration after } 2 \text { months } \\
\text { was significantly higher in (iv) }\end{array}$ & [33] \\
\hline $\begin{array}{c}\text { Osteoblast cell line } \\
\text { (MC3T3-E1) } / 4 \times 2 \mathrm{~mm} \\
\text { Mandibular peri-implant } \\
\text { defect (dog) }\end{array}$ & $\begin{array}{l}\text { (i) } \\
\text { (ii) }\end{array}$ & $\begin{array}{l}\text { 3D-printed PCL/PLGA/ } \beta \text {-TCP membrane } \\
\text { Collagen membrane }\end{array}$ & $\begin{array}{l}\text { - } \\
\text { No difference was observed in } \\
\text { osteogenic differentiation between } \\
\text { (i) and (ii) on day } 14 \text {. } \\
\text { (i) had similar levels of } \\
\text { biocompatibility and bone } \\
\text { regeneration to (ii) }\end{array}$ & [5] \\
\hline $\begin{array}{l}\quad 7 \times 5 \times 5 \mathrm{~mm} \\
\text { Mandibular defect }(\mathrm{dog})\end{array}$ & $\begin{array}{l}\text { (i) } \\
\text { (ii) } \\
\text { (iii) }\end{array}$ & $\begin{array}{l}\text { 3D-printed PCL membrane } \\
\text { 3D-printed PCL/ } \beta \text {-TCP membrane } \\
\text { Collagen membrane }\end{array}$ & $\begin{array}{l}\text { (ii) had significantly higher new } \\
\text { bone plus bone substitute } \\
\text { percentages values than (i) and (iii) }\end{array}$ & {$[34]$} \\
\hline $\begin{array}{l}8 \mathrm{~mm} \text { Calvarial defect } \\
\text { (rabbit) }\end{array}$ & $\begin{array}{l}\text { (i) } \\
\text { (ii) } \\
\text { (iii) }\end{array}$ & $\begin{array}{l}\text { No membrane } \\
\text { 3D-printed PCL/PLGA/ } \beta \text {-TCP membrane } \\
\text { 3D-printed } \\
\text { PCL/PLGA/ } \beta \text {-TCP/rhBMP-2 membrane }\end{array}$ & $\begin{array}{l}\text { - (iii) exhibited the greatest amount of } \\
\text { new bone formation, followed by (ii) } \\
\text { and (i) at } 4 \text { and } 8 \text { weeks } \\
\text { post-implantation, and these were } \\
\text { significantly different }\end{array}$ & [35] \\
\hline
\end{tabular}


Poly(lactic-co-glycolic acid) (PLGA) is a copolymer that can be prepared in different forms of copolymer depending on the ratio of PLA and PGA, with the advantages of biocompatibility, biodegradability, and processability [7,36]. Bi-layer PLGA membrane is composed of a thin dense film that prevents the ingrowth of epithelial cells and a thick micro-fibrous layer that stabilizes blood clots and helps cell colonization and bone regeneration [37]. Its mechanical properties are sufficient for clinical use and it has a similar absorption rate to PLGA membrane and a higher rate of new bone formation than PLGA membrane [32].

The blended PCL/biphasic calcium phosphate (BCP) membrane produced significantly higher bone regeneration than PCL membrane, due to the osteoconductivity of BCP [33]. BCP consists of $\mathrm{HA}$ and $\beta-\mathrm{TCP}$, which affects the bioactivity and substitution rate depending on the ratio of HA and $\beta$-TCP [38].

Many studies have been conducted recently on membranes using three-dimensional (3D) printing technology to produce freeform membranes. A study of 3D-printed PCL/PLGA/ $\beta$-TCP membrane showed similar biocompatibility and bone regeneration compared to collagen membrane [5]. PCL/PLGA/ $\beta$-TCP membrane has the biological advantage of PLGA with good cell affinity, the mechanical advantage of PCL with good physical properties, and the osteoconductivity of $\beta$-TCP $[5,39]$. PCL/PLGA/ $\beta$-TCP membrane had satisfactory flexibility, space-making ability, and sufficient physical properties for use in GBR [6]. In another study, 3D-printed PCL/ $\beta$-TCP membrane had better biocompatibility and bone regeneration than PCL membrane and collagen membrane [34]. Recombinant human (rh) BMP-2-loaded PCL/PLGA/ $\beta$-TCP membrane fabricated via 3D printing showed better bone regeneration than the control and PCL/PLGA/ $\beta$-TCP membrane due to rhBMP-2 with osteoinductivity [35].

\section{Platelet Rich Fibrin}

Platelet rich fibrin (PRF) is a second-generation platelet concentrate consisting of fibrin membrane enriched with platelets, leukocytes, growth factors, and cytokines [40,41]. PRF is autologous in nature, gradually resorbed over time, and healing biomaterial with potential for bone and soft tissue regeneration [41]. PRF is simpler and faster to prepare compared to platelet rich plasma (PRP), because it is only centrifuged blood without any additives such as anticoagulant, bovine thrombin, and any other gelling agent [42,43]. It is also more suitable for manipulation or suturing [42]. In addition, it is cost effective and carries no risk of allergic reaction [43,44]. The method of preparation of PRF is shown in Figure 1 [40]. At this time, centrifugation should begin within $90 \mathrm{~s}$, since the size decreases as the time from the blood draw to the start of centrifugation is delayed [45].

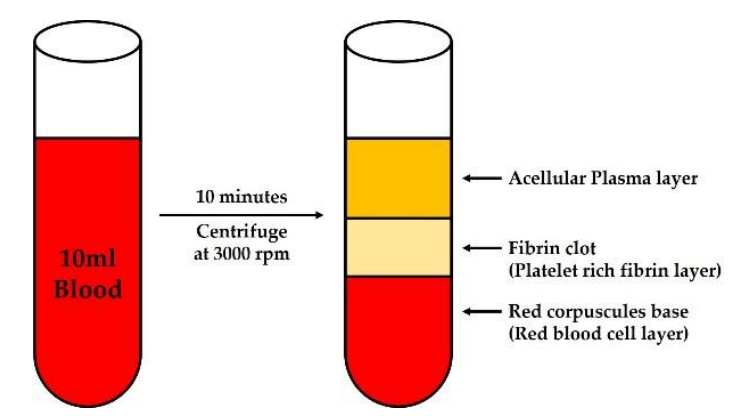

Figure 1. The method of preparation of platelet rich fibrin. A blood sample is taken in $10 \mathrm{~mL}$ tubes without anticoagulants and immediately centrifuged at $3000 \mathrm{rpm}$ for $10 \mathrm{~min}$. A Fibrin clot is then obtained in the middle of the tube, between the red corpuscles and the acellular plasma.

PRF could easily be compressed into PRF membrane, by pressing the PRF clot between two pieces of surgical gauze [41,44]. PRF membrane has been successful in oral mucosal defects [44,46], periodontal bone defects [41,47], gingival recession defects [42], and tympanic membrane perforation [48]. PRF membrane offers acceptable elasticity and may stretch to some extent to cover wound edges, but it 
lacks rigidity and needs to be carefully handled to prevent tearing [41,44]. Because PRF membrane is resorbed within two weeks or less at the implantation site, it can barely maintain sufficient space for bone regeneration [49].

Several studies have been conducted to overcome these drawbacks. Heat-compression of the PRF membrane results in delayed degradation up to 4 weeks without sacrificing its biocompatibility by reducing the porosity and surface area, and it could easily be prepared at chair-side and applied as a barrier membrane [49]. In addition, Ankaferd Blood Stopper, a standardized herbal extract approved for external bleeding hemostasis, loaded PRF improved mechanical properties by reducing porosity similar to heat compressed PRF membrane [50]. However, advanced research is required on its biological properties.

As an improved formulation of PRF, concentration growth factor (CGF) was introduced by Sacco in 2006 [51,52]. It is considered as a new fibrin matrix block made by separating it from a centrifuged blood sample using a special device in a manner similar to PRF [52]. CGF is a bigger fibrin matrix with a higher concentration of growth factors because of the different centrifugation speed [52]. Clinically, CGF has showed good bone regeneration ability in maxillary sinus and alveolar bone augmentation, and it was reported that the use of CGF membrane showed bone regeneration similar to collagen membrane in GBR $[53,54]$.

\section{Silk-Based Materials}

Silk, a natural macromolecule produced by Bombyx mori, has been used as a suturing material [55]. Silk membrane has excellent biocompatibility and mechanical strength, and a competitive price without the risk of disease transmission of mammalian origin [1,56,57]. Since silk degrades very slowly, it can generally be considered to be non-degradable [58]. However, alterations in silk processing can accelerate degradation to meet the clinical requirements by changing the conformation of the protein structure $[58,59]$. Thus, silk has been developed as a novel degradable membrane.

Silk fibers are composed of sericin, a glue-like protein that encases and binds fibroin fibers together, and fibroin, which is the core filament responsible for the elasticity of silk $[58,60]$. Sericin has been reported to cause adverse effects in those with biocompatibility and hypersensitivity to silk [58]. Therefore, silk fibroin membranes from which sericin was removed via degumming have been studied [55,57,59,61-65]. Silk fibroin has the advantages of low inflammation, and excellent biocompatibility and mechanical properties $[1,62]$. Silk fibroin membrane, combined with other biomaterials, has also been reported to improve bone regeneration (Table 3).

Table 3. Experimental studies evaluating the performance of modified silk membranes.

\begin{tabular}{|c|c|c|c|c|}
\hline $\begin{array}{l}\text { Experimental } \\
\text { Model }\end{array}$ & (Me & $\begin{array}{l}\text { Experimental Groups } \\
\text { nbrane with/without new Material) }\end{array}$ & Main Findings & Reference \\
\hline $\begin{array}{l}8 \mathrm{~mm} \text { Calvarial } \\
\text { defect (rat) }\end{array}$ & $\begin{array}{l}\text { (i) } \\
\text { (ii) } \\
\text { (iii) }\end{array}$ & $\begin{array}{l}\text { Chitosan/fibroin-HA membrane } \\
\text { Collagen membrane (Bio-Gide) } \\
\text { No membrane }\end{array}$ & $\begin{array}{l}\text { - Significant difference in bone volume and } \\
\text { bone mineral density between (i)/(ii) and (iii) } \\
\text { - } \quad \text { No significant difference between (i) and (ii) }\end{array}$ & [62] \\
\hline $\begin{array}{l}8 \text { mm Calvarial } \\
\text { defect (rat) }\end{array}$ & & $\begin{array}{l}\text { Chitin/fibroin-HA membrane } \\
\text { Collagen membrane (Bio-Gide) } \\
\text { No membrane }\end{array}$ & $\begin{array}{l}\text { - Significant difference in bone volume and } \\
\text { bone mineral density between (i)/(ii) and (iii) } \\
\text { - } \quad \text { No significant difference between (i) and (ii) }\end{array}$ & [63] \\
\hline $\begin{array}{l}8 \text { mm Calvarial } \\
\text { defect (rabbit) }\end{array}$ & $\begin{array}{l}\text { (i) } \\
\text { (ii) } \\
\text { (iii) }\end{array}$ & $\begin{array}{l}\text { 4-HR-incorporated silk } \\
\text { fabric membrane } \\
\text { Silk fabric membrane } \\
\text { No membrane }\end{array}$ & $\begin{array}{l}\text { - (i) and (ii) produced significantly higher bone } \\
\text { regeneration than (iii) } \\
\text { - } \quad \text { However, there was no significant difference } \\
\text { between (i) and (ii) } \\
\text { - The amount of residual membrane was } \\
\text { significantly higher in (ii) than in (i) }\end{array}$ & [61] \\
\hline $\begin{array}{l}3 \times 5 \mathrm{~mm} \\
\text { peri-implant defect } \\
\quad \text { (Rabbit tibia) }\end{array}$ & $\begin{array}{l}\text { (i) } \\
\text { (ii) }\end{array}$ & $\begin{array}{l}\text { No membrane } \\
\text { Silk fibroin with } 4 \text {-HR membrane }\end{array}$ & $\begin{array}{l}\text { - The gained bone volume was significantly } \\
\text { higher in (ii) than in (i) }\end{array}$ & [66] \\
\hline
\end{tabular}

Chitosan/fibroin/HA membrane, with osteoconductivity of HA, has been reported to produce similar bone regeneration to collagen membrane. Chitosan, derived from the natural polymer 
chitin, is a polyheterosaccharide with flexibility, antibacterial activity, and a hydrophilic surface that promotes cell adhesion, proliferation, and differentiation [62]. Fibroin/HA membrane containing chitin, an acetylated chitosan with antibacterial and anti-inflammatory activity, instead of chitosan, also has significant effects on new bone formation [63].

Silk fibroin membrane with 4-hexylresorcinol (4-HR) produced significantly more new bone formation than an unfilled control group [61,66]. 4-HR is an antimicrobial agent that inhibits the inflammatory response and accelerates the partial degradation of the silk membrane [65-67].

Silk membrane is manufactured using various methods such as electrospinning $[1,64,68]$, casting $[55-57,63,66]$, and simple separation $[68,69]$. Scanning electron microscope images of silk membranes manufactured by each technique are shown in Figure 2. Regardless of the production method, silk membranes produce effective bone regeneration without inflammation.

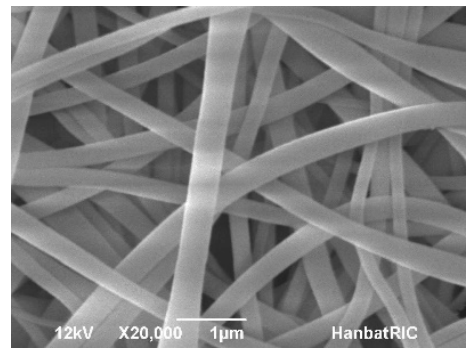

(a)

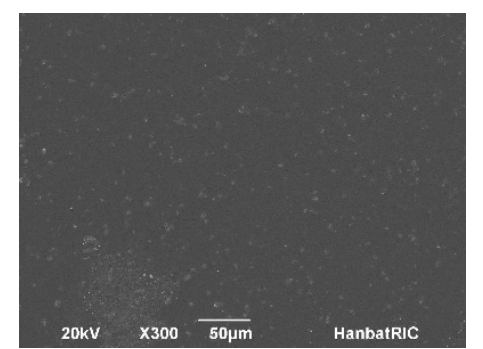

(b)

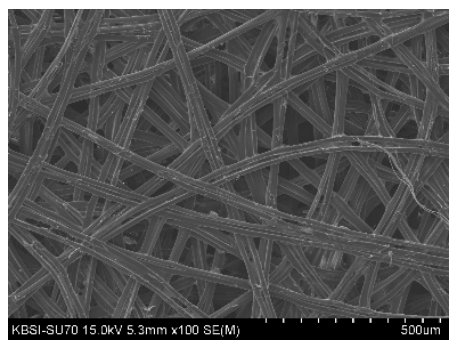

(c)

Figure 2. Scanning electron microscope (SEM) images of silk membranes manufactured using each technique: (a) electrospinning; (b) casting; and (c) simple separation. Images were taken after sample preparation using SU-70 (Hitachi, Japan) at $5 \mathrm{keV}$.

Electrospinning produces nanofibers using high voltage [70]. Silk fibroin nanofibrous membrane thus exhibited significantly higher tensile strength than collagen membrane and improved new bone regeneration without any adverse inflammatory reactions by promoting early osteogenesis $[1,64]$.

The casting technique produces a transparent silk fibroin membrane, and this film type membrane showed higher new bone formation than the unfilled control group [55]. Compared to collagen membrane, the film type of membrane produced similar bone regeneration without any adverse inflammatory reactions [57].

The simple separation technique separates the silk cocoon, which consists of multiple layers, through mechanical peeling to obtain membranes of various thicknesses $[69,71]$. It was recently reported that sericin does not cause inflammation [72], and studies have been conducted on membranes using whole silk without degumming. The middle layer of a silk cocoon was more effective at bone regeneration than unprocessed silk cocoon [69]. Furthermore, a thicker silk membrane was superior for bone regeneration compared to the various thicknesses of silk membrane [68]. Silk membrane produced via the simple separation technique has no risk of residual bio-hazard salts such as those added during the degumming process. However, it is not possible to produce large membranes using this technique, because the size of the silk membrane produced depends on the size of the cocoon [14]. Therefore, further studies are required on the fabrication of silk membranes of various sizes.

\section{Conclusions}

Several commercial resorbable membranes have advantages and disadvantages. Studies on new materials have been conducted to overcome the disadvantages and to improve the bone regeneration ability of these membranes. Further research is necessary to commercialize these membranes using new materials.

Author Contributions: Y.-Y.J. and J.-H.O. write the first draft and reviewed and wrote the paper. All the authors read and approved the final version of the manuscript. 
Funding: This research received no external funding.

Acknowledgments: This work was carried out with the support of the "Cooperative Research Program for Agriculture Science and Technology Development (Project No. PJ01313902)", Rural Development Administration, Republic of Korea.

Conflicts of Interest: The authors declare no conflict of interest.

\section{References}

1. Lu, S.; Wang, P.; Zhang, F.; Zhou, X.; Zuo, B.; You, X.; Gao, Y.; Liu, H.; Tang, H. A novel silk fibroin nanofibrous membrane for guided bone regeneration: A study in rat calvarial defects. Am. J. Transl. Res. 2015, 7, 2244-2253. [PubMed]

2. Cha, H.S.; Kim, J.W.; Hwang, J.H.; Ahn, K.M. Frequency of bone graft in implant surgery. Maxillofac. Plast. Reconstr. Surg. 2016, 38, 19. [CrossRef] [PubMed]

3. Bottino, M.C.; Thomas, V.; Schmidt, G.; Vohra, Y.K.; Chu, T.M.; Kowolik, M.J.; Janowski, G.M. Recent advances in the development of GTR/GBR membranes for periodontal regeneration-A materials perspective. Dent. Mater. 2012, 28, 703-721. [CrossRef] [PubMed]

4. Gentile, P.; Chiono, V.; Tonda-Turo, C.; Ferreira, A.M.; Ciardelli, G. Polymeric membranes for guided bone regeneration. Biotechnol. J. 2011, 6, 1187-1197. [CrossRef] [PubMed]

5. Won, J.Y.; Park, C.Y.; Bae, J.H.; Ahn, G.; Kim, C.; Lim, D.H.; Cho, D.W.; Yun, W.S.; Shim, J.H.; Huh, J.B. Evaluation of 3D printed PCL/PLGA/beta-TCP versus collagen membranes for guided bone regeneration in a beagle implant model. Biomed. Mater. 2016, 11, 055013. [CrossRef] [PubMed]

6. Shim, J.H.; Huh, J.B.; Park, J.Y.; Jeon, Y.C.; Kang, S.S.; Kim, J.Y.; Rhie, J.W.; Cho, D.W. Fabrication of blended polycaprolactone/poly(lactic-co-glycolic acid)/beta-tricalcium phosphate thin membrane using solid freeform fabrication technology for guided bone regeneration. Tissue Eng. Part A 2013, 19, 317-328. [CrossRef] [PubMed]

7. Hua, N.; Ti, V.L.; Xu, Y. Biodegradable effect of PLGA membrane in alveolar bone regeneration on beagle dog. Cell Biochem. Biophys. 2014, 70, 1051-1055. [CrossRef] [PubMed]

8. Scantlebury, T.V. 1982-1992: A Decade of Technology Development for Guided Tissue Regeneration. J. Periodontol. 1993, 64 (Suppl. 11S), 1129-1137. [CrossRef] [PubMed]

9. Caballe-Serrano, J.; Munar-Frau, A.; Ortiz-Puigpelat, O.; Soto-Penaloza, D.; Penarrocha, M.; HernandezAlfaro, F. On the search of the ideal barrier membrane for guided bone regeneration. J. Clin. Exp. Dent. 2018, 10, e477-e483. [CrossRef] [PubMed]

10. Alpar, B.; Leyhausen, G.; Gunay, H.; Geurtsen, W. Compatibility of resorbable and nonresorbable guided tissue regeneration membranes in cultures of primary human periodontal ligament fibroblasts and human osteoblast-like cells. Clin. Oral Investig. 2000, 4, 219-225. [CrossRef] [PubMed]

11. Lee, S.B.; Kwon, J.S.; Lee, Y.K.; Kim, K.M.; Kim, K.N. Bioactivity and mechanical properties of collagen composite membranes reinforced by chitosan and beta-tricalcium phosphate. J. Biomed. Mater. Res. Part $B$ Appl. Biomater. 2012, 100, 1935-1942. [CrossRef] [PubMed]

12. Chu, C.; Deng, J.; Sun, X.; Qu, Y.; Man, Y. Collagen Membrane and Immune Response in Guided Bone Regeneration: Recent Progress and Perspectives. Tissue Eng. Part B Rev. 2017, 23, 421-435. [CrossRef] [PubMed]

13. Verissimo, D.M.; Leitao, R.F.; Figueiro, S.D.; Goes, J.C.; Lima, V.; Silveira, C.O.; Brito, G.A. Guided bone regeneration produced by new mineralized and reticulated collagen membranes in critical-sized rat calvarial defects. Exp. Biol. Med. 2015, 240, 175-184. [CrossRef] [PubMed]

14. Lee, S.W.; Kim, S.G. Membranes for the Guided Bone Regeneration. Maxillofac. Plast. Reconstr. Surg. 2014, 36, 239-246. [CrossRef] [PubMed]

15. Tal, H.; Kozlovsky, A.; Artzi, Z.; Nemcovsky, C.E.; Moses, O. Long-term bio-degradation of cross-linked and non-cross-linked collagen barriers in human guided bone regeneration. Clin. Oral Implants Res. 2008, 19, 295-302. [CrossRef] [PubMed]

16. Bunyaratavej, P.; Wang, H.L. Collagen membranes: A review. J. Periodontol. 2001, 72, 215-229. [CrossRef] [PubMed]

17. Speer, D.P.; Chvapil, M.; Eskelson, C.D.; Ulreich, J. Biological effects of residual glutaraldehyde in glutaraldehyde-tanned collagen biomaterials. J. Biomed. Mater. Res. 1980, 14, 753-764. [CrossRef] [PubMed] 
18. Simmons, D.M.; Kearney, J.N. Evaluation of collagen cross-linking techniques for the stabilization of tissue matrices. Biotechnol. Appl. Biochem. 1993, 17 Pt 1, 23-29.

19. Zahedi, S.; Legrand, R.; Brunel, G.; Albert, A.; Dewe, W.; Coumans, B.; Bernard, J.P. Evaluation of a diphenylphosphorylazide-crosslinked collagen membrane for guided bone regeneration in mandibular defects in rats. J. Periodontol. 1998, 69, 1238-1246. [CrossRef] [PubMed]

20. Zahedi, C.S.; Miremadi, S.A.; Brunel, G.; Rompen, E.; Bernard, J.P.; Benque, E. Guided tissue regeneration in human Class II furcation defects using a diphenylphosphorylazide-cross-linked collagen membrane: A consecutive case series. J. Periodontol. 2003, 74, 1071-1079. [CrossRef] [PubMed]

21. Barnes, C.P.; Pemble, C.W.; Brand, D.D.; Simpson, D.G.; Bowlin, G.L. Cross-linking electrospun type II collagen tissue engineering scaffolds with carbodiimide in ethanol. Tissue Eng. 2007, 13, 1593-1605. [CrossRef] [PubMed]

22. Park, J.Y.; Jung, I.H.; Kim, Y.K.; Lim, H.C.; Lee, J.S.; Jung, U.W.; Choi, S.H. Guided bone regeneration using 1-ethyl-3-(3-dimethylaminopropyl) carbodiimide (EDC)-cross-linked type-I collagen membrane with biphasic calcium phosphate at rabbit calvarial defects. Biomater. Res. 2015, 19, 15. [CrossRef] [PubMed]

23. Chu, C.; Deng, J.; Hou, Y.; Xiang, L.; Wu, Y.; Qu, Y.; Man, Y. Application of PEG and EGCG modified collagen-base membrane to promote osteoblasts proliferation. Mater. Sci. Eng. C Mater. Biol. Appl. 2017, 76, 31-36. [CrossRef] [PubMed]

24. Chu, C.; Deng, J.; Xiang, L.; Wu, Y.; Wei, X.; Qu, Y.; Man, Y. Evaluation of epigallocatechin-3-gallate (EGCG) cross-linked collagen membranes and concerns on osteoblasts. Mater. Sci. Eng. C Mater. Biol. Appl. 2016, 67, 386-394. [CrossRef] [PubMed]

25. Chu, C.; Deng, J.; Man, Y.; Qu, Y. Evaluation of nanohydroxyapaptite (nano-HA) coated epigallocatechin3-gallate (EGCG) cross-linked collagen membranes. Mater. Sci. Eng. C Mater. Biol. Appl. 2017, 78, 258-264. [CrossRef] [PubMed]

26. Jin, Q.; Wang, X.M.; Wang, X.F.; Li, X.D.; Ma, J.F. The efficacy of collagen-hydroxyapatite composite membrane on bone regeneration. West China J. Stomatol. 2011, 29, 21-26.

27. Teng, S.H.; Lee, E.J.; Wang, P.; Shin, D.S.; Kim, H.E. Three-layered membranes of collagen/hydroxyapatite and chitosan for guided bone regeneration. J. Biomed. Mater. Res. Part B Appl. Biomater. 2008, 87, 132-138. [CrossRef] [PubMed]

28. Jo, J.Y.; Jeong, S.I.; Shin, Y.M.; Kang, S.S.; Kim, S.E.; Jeong, C.M.; Huh, J.B. Sequential delivery of BMP-2 and BMP-7 for bone regeneration using a heparinized collagen membrane. Int. J. Oral Maxillofac. Surg. 2015, 44, 921-928. [CrossRef] [PubMed]

29. Yamano, S.; Haku, K.; Yamanaka, T.; Dai, J.; Takayama, T.; Shohara, R.; Tachi, K.; Ishioka, M.; Hanatani, S.; Karunagaran, S.; et al. The effect of a bioactive collagen membrane releasing PDGF or GDF-5 on bone regeneration. Biomaterials 2014, 35, 2446-2453. [CrossRef] [PubMed]

30. Zhao, L.; Li, N.; Wang, K.; Shi, C.; Zhang, L.; Luan, Y. A review of polypeptide-based polymersomes. Biomaterials 2014, 35, 1284-1301. [CrossRef] [PubMed]

31. Elgali, I.; Omar, O.; Dahlin, C.; Thomsen, P. Guided bone regeneration: Materials and biological mechanisms revisited. Eur. J. Oral Sci. 2017, 125, 315-337. [CrossRef] [PubMed]

32. Yoshimoto, I.; Sasaki, J.I.; Tsuboi, R.; Yamaguchi, S.; Kitagawa, H.; Imazato, S. Development of layered PLGA membranes for periodontal tissue regeneration. Dent. Mater. 2018, 34, 538-550. [CrossRef] [PubMed]

33. Padalhin, A.R.; Thuy Ba Linh, N.; Ki Min, Y.; Lee, B.T. Evaluation of the cytocompatibility hemocompatibility in vivo bone tissue regenerating capability of different PCL blends. J. Biomater. Sci. Polym. Ed. 2014, 25, 487-503. [CrossRef] [PubMed]

34. Shim, J.-H.; Won, J.-Y.; Park, J.-H.; Bae, J.-H.; Ahn, G.; Kim, C.-H.; Lim, D.-H.; Cho, D.-W.; Yun, W.-S.; Bae, E.-B.; et al. Effects of 3D-Printed Polycaprolactone/beta-Tricalcium Phosphate Membranes on Guided Bone Regeneration. Int. J. Mol. Sci. 2017, 18, 899. [CrossRef] [PubMed]

35. Shim, J.H.; Yoon, M.C.; Jeong, C.M.; Jang, J.; Jeong, S.I.; Cho, D.W.; Huh, J.B. Efficacy of rhBMP-2 loaded PCL/PLGA/beta-TCP guided bone regeneration membrane fabricated by 3D printing technology for reconstruction of calvaria defects in rabbit. Biomed. Mater. 2014, 9, 065006. [CrossRef] [PubMed]

36. Gentile, P.; Chiono, V.; Carmagnola, I.; Hatton, P.V. An overview of poly(lactic-co-glycolic) acid (PLGA)-based biomaterials for bone tissue engineering. Int. J. Mol. Sci. 2014, 15, 3640-3659. [CrossRef] [PubMed] 
37. Hoornaert, A.; d'Arros, C.; Heymann, M.F.; Layrolle, P. Biocompatibility, resorption and biofunctionality of a new synthetic biodegradable membrane for guided bone regeneration. Biomed. Mater. 2016, 11, 045012. [CrossRef] [PubMed]

38. Nevins, M.; Nevins, M.L.; Schupbach, P.; Kim, S.W.; Lin, Z.; Kim, D.M. A prospective, randomized controlled preclinical trial to evaluate different formulations of biphasic calcium phosphate in combination with a hydroxyapatite collagen membrane to reconstruct deficient alveolar ridges. J. Oral Implantol. 2013, 39, 133-139. [CrossRef] [PubMed]

39. Shim, J.H.; Kim, J.Y.; Park, M.; Park, J.; Cho, D.W. Development of a hybrid scaffold with synthetic biomaterials and hydrogel using solid freeform fabrication technology. Biofabrication 2011, 3, 034102. [CrossRef] [PubMed]

40. Dohan, D.M.; Choukroun, J.; Diss, A.; Dohan, S.L.; Dohan, A.J.; Mouhyi, J.; Gogly, B. Platelet-rich fibrin (PRF): A second-generation platelet concentrate. Part I: Technological concepts and evolution. Oral Surg. Oral Med. Oral Pathol. Oral Radiol. Endod. 2006, 101, e37-e44. [CrossRef] [PubMed]

41. Joseph, V.R.; Sam, G.; Amol, N.V. Clinical evaluation of autologous platelet rich fibrin in horizontal alveolar bony defects. J. Clin. Diagn. Res. JCDR 2014, 8, ZC43-ZC47. [CrossRef] [PubMed]

42. Moraschini, V.; Barboza Edos, S. Use of Platelet-Rich Fibrin Membrane in the Treatment of Gingival Recession: A Systematic Review and Meta-Analysis. J. Periodontol. 2016, 87, 281-290. [CrossRef] [PubMed]

43. Sam, G.; Vadakkekuttical, R.J.; Amol, N.V. In vitro evaluation of mechanical properties of platelet-rich fibrin membrane and scanning electron microscopic examination of its surface characteristics. J. Indian Soc. Periodontol. 2015, 19, 32-36. [CrossRef] [PubMed]

44. Mohanty, S.; Pathak, H.; Dabas, J. Platelet rich fibrin: A new covering material for oral mucosal defects. J. Oral Biol. Craniofac. Res. 2014, 4, 144-146. [CrossRef] [PubMed]

45. Miron, R.J.; Dham, A.; Dham, U.; Zhang, Y.; Pikos, M.A.; Sculean, A. The effect of age, gender, and time between blood draw and start of centrifugation on the size outcomes of platelet-rich fibrin (PRF) membranes. Clin. Oral Investig. 2018, 1-7. [CrossRef] [PubMed]

46. Debnath, K.; Chatterjee, A. Management of recurrent pyogenic granuloma with platelet-rich fibrin membrane. J. Indian Soc. Periodontol. 2018, 22, 360-364. [CrossRef] [PubMed]

47. Ranganathan, A.T.; Chandran, C.R. Platelet-rich fibrin in the treatment of periodontal bone defects. J. Contemp. Dent. Pract. 2014, 15, 372-375. [CrossRef] [PubMed]

48. Gur, O.E.; Ensari, N.; Ozturk, M.T.; Boztepe, O.F.; Gun, T.; Selcuk, O.T.; Renda, L. Use of a platelet-rich fibrin membrane to repair traumatic tympanic membrane perforations: A comparative study. Acta Oto-Laryngol. 2016, 136, 1017-1023. [CrossRef] [PubMed]

49. Kawase, T.; Kamiya, M.; Kobayashi, M.; Tanaka, T.; Okuda, K.; Wolff, L.F.; Yoshie, H. The heat-compression technique for the conversion of platelet-rich fibrin preparation to a barrier membrane with a reduced rate of biodegradation. J. Biomed. Mater. Res. Part B Appl. Biomater. 2015, 103, 825-831. [CrossRef] [PubMed]

50. Aktas, A.; Ozer, T.; Sen, M.; Turk, M.; Karabulut, E. Comparison of the mechanical properties of platelet-rich fibrin and ankaferd blood stopper-loaded platelet-rich fibrin. Niger. J. Clin. Pract. 2018, 21, 1087-1092. [CrossRef] [PubMed]

51. Isobe, K.; Watanebe, T.; Kawabata, H.; Kitamura, Y.; Okudera, T.; Okudera, H.; Uematsu, K.; Okuda, K.; Nakata, K.; Tanaka, T.; et al. Mechanical and degradation properties of advanced platelet-rich fibrin (A-PRF), concentrated growth factors (CGF), and platelet-poor plasma-derived fibrin (PPTF). Int. J. Implant Dent. 2017, 3, 17. [CrossRef] [PubMed]

52. Rodella, L.F.; Favero, G.; Boninsegna, R.; Buffoli, B.; Labanca, M.; Scari, G.; Sacco, L.; Batani, T.; Rezzani, R. Growth factors, CD34 positive cells, and fibrin network analysis in concentrated growth factors fraction. Microsc. Res. Tech. 2011, 74, 772-777. [CrossRef] [PubMed]

53. Sohn, D.S.; Heo, J.U.; Kwak, D.H.; Kim, D.E.; Kim, J.M.; Moon, J.W.; Lee, J.H.; Park, I.S. Bone regeneration in the maxillary sinus using an autologous fibrin-rich block with concentrated growth factors alone. Implant Dent. 2011, 20, 389-395. [CrossRef] [PubMed]

54. Isler, S.C.; Soysal, F.; Ceyhanli, T.; Bakirarar, B.; Unsal, B. Regenerative surgical treatment of peri-implantitis using either a collagen membrane or concentrated growth factor: A 12-month randomized clinical trial. Clin. Implant Dent. Relat. Res. 2018, 20, 703-712. [CrossRef] [PubMed] 
55. Song, J.Y.; Kim, S.G.; Lee, J.W.; Chae, W.S.; Kweon, H.; Jo, Y.Y.; Lee, K.G.; Lee, Y.C.; Choi, J.Y.; Kim, J.Y. Accelerated healing with the use of a silk fibroin membrane for the guided bone regeneration technique. Oral Surg. Oral Med. Oral Pathol. Oral Radiol. Endod. 2011, 112, e26-e33. [CrossRef] [PubMed]

56. Smeets, R.; Knabe, C.; Kolk, A.; Rheinnecker, M.; Grobe, A.; Heiland, M.; Zehbe, R.; Sachse, M.; Grosse-Siestrup, C.; Woltje, M.; et al. Novel silk protein barrier membranes for guided bone regeneration. J. Biomed. Mater. Res. Part B Appl. Biomater. 2017, 105, 2603-2611. [CrossRef] [PubMed]

57. Kim, J.Y.; Yang, B.E.; Ahn, J.H.; Park, S.O.; Shim, H.W. Comparable efficacy of silk fibroin with the collagen membranes for guided bone regeneration in rat calvarial defects. J. Adv. Prosthodont. 2014, 6, 539-546. [CrossRef] [PubMed]

58. Altman, G.H.; Diaz, F.; Jakuba, C.; Calabro, T.; Horan, R.L.; Chen, J.; Lu, H.; Richmond, J.; Kaplan, D.L. Silk-based biomaterials. Biomaterials 2003, 24, 401-416. [CrossRef]

59. Cai, Y.; Guo, J.; Chen, C.; Yao, C.; Chung, S.M.; Yao, J.; Lee, I.S.; Kong, X. Silk fibroin membrane used for guided bone tissue regeneration. Mater. Sci. Eng. C Mater. Biol. Appl. 2017, 70, 148-154. [CrossRef] [PubMed]

60. Soundarya, S.P.; Menon, A.H.; Chandran, S.V.; Selvamurugan, N. Bone tissue engineering: Scaffold preparation using chitosan and other biomaterials with different design and fabrication techniques. Int. J. Biol. Macromol. 2018, 119, 1228-1239. [CrossRef] [PubMed]

61. Lee, S.W.; Um, I.C.; Kim, S.G.; Cha, M.S. Evaluation of bone formation and membrane degradation in guided bone regeneration using a 4-hexylresorcinol-incorporated silk fabric membrane. Maxillofac. Plast. Reconstr. Surg. 2015, 37, 32. [CrossRef] [PubMed]

62. Song, J.M.; Shin, S.H.; Kim, Y.D.; Lee, J.Y.; Baek, Y.J.; Yoon, S.Y.; Kim, H.S. Comparative study of chitosan/fibroin-hydroxyapatite and collagen membranes for guided bone regeneration in rat calvarial defects: Micro-computed tomography analysis. Int. J. Oral Sci. 2014, 6, 87-93. [CrossRef] [PubMed]

63. Baek, Y.J.; Kim, J.H.; Song, J.M.; Yoon, S.Y.; Kim, H.S.; Shin, S.H. Chitin-fibroin-hydroxyapatite membrane for guided bone regeneration: Micro-computed tomography evaluation in a rat model. Maxillofac. Plast. Reconstr. Surg. 2016, 38, 14. [CrossRef] [PubMed]

64. Kim, K.H.; Jeong, L.; Park, H.N.; Shin, S.Y.; Park, W.H.; Lee, S.C.; Kim, T.I.; Park, Y.J.; Seol, Y.J.; Lee, Y.M.; et al. Biological efficacy of silk fibroin nanofiber membranes for guided bone regeneration. J. Biotechnol. 2005, 120, 327-339. [CrossRef] [PubMed]

65. Kweon, H.; Kim, S.G.; Choi, J.Y. Inhibition of foreign body giant cell formation by 4-hexylresorcinol through suppression of diacylglycerol kinase delta gene expression. Biomaterials 2014, 35, 8576-8584. [CrossRef] [PubMed]

66. Lee, S.W.; Kim, S.G.; Song, J.Y.; Kweon, H.; Jo, Y.Y.; Lee, K.G.; Kang, S.W.; Yang, B.E. Silk fibroin and 4-hexylresorcinol incorporation membrane for guided bone regeneration. J. Craniofac. Surg. 2013, 24, 1927-1930. [CrossRef] [PubMed]

67. Kang, Y.J.; Noh, J.E.; Lee, M.J.; Chae, W.S.; Lee, S.Y.; Kim, S.G. The effect of 4-hexylresorcinol on xenograft degradation in a rat calvarial defect model. Maxillofac. Plast. Reconstr. Surg. 2016, 38, 29. [CrossRef] [PubMed]

68. Seok, H.; Kim, M.K.; Kim, S.G.; Kweon, H. Comparison of silkworm-cocoon-derived silk membranes of two different thicknesses for guided bone regeneration. J. Craniofac. Surg. 2014, 25, 2066-2069. [CrossRef] [PubMed]

69. Kim, S.G.; Kim, M.K.; Kweon, H.; Jo, Y.Y.; Lee, K.G.; Lee, J.K. Comparison of unprocessed silk cocoon and silk cocoon middle layer membranes for guided bone regeneration. Maxillofac. Plast. Reconstr. Surg. 2016, 38, 11. [CrossRef] [PubMed]

70. Min, B.M.; Lee, G.; Kim, S.H.; Nam, Y.S.; Lee, T.S.; Park, W.H. Electrospinning of silk fibroin nanofibers and its effect on the adhesion and spreading of normal human keratinocytes and fibroblasts in vitro. Biomaterials 2004, 25, 1289-1297. [CrossRef] [PubMed]

71. Zhang, J.; Kaur, J.; Rajkhowa, R.; Li, J.L.; Liu, X.Y.; Wang, X.G. Mechanical properties and structure of silkworm cocoons: A comparative study of Bombyx mori, Antheraea assamensis, Antheraea pernyi and Antheraea mylitta silkworm cocoons. Mater. Sci. Eng. C Mater. Biol. Appl. 2013, 33, 3206-3213. [CrossRef] [PubMed]

72. Aramwit, P.; Kanokpanont, S.; De-Eknamkul, W.; Srichana, T. Monitoring of inflammatory mediators induced by silk sericin. J. Biosci. Bioeng. 2009, 107, 556-561. [CrossRef] [PubMed]

(C) 2018 by the authors. Licensee MDPI, Basel, Switzerland. This article is an open access article distributed under the terms and conditions of the Creative Commons Attribution (CC BY) license (http://creativecommons.org/licenses/by/4.0/). 